\title{
Socio-Cultural Responses to The Post- Nationalization of Dutch Companies in 1958-1966
}

\author{
Waskito Widi Wardojo $^{1 *}$, Singgih Tri Sulistiyono ${ }^{1}$, Endang Susilowati ${ }^{1}$, Yety \\ Rochwulaningsih ${ }^{1}$ \\ ${ }^{1}$ Doctoral Program of History, Faculty of Humanities, University of Diponegoro, Semarang, \\ Indonesia.
}

\begin{abstract}
The Dutch company nationalization policy in 1958 had a broad impact in various fields related to the economic, political, and socio-cultural aspects. Due to the presence of anti-foreign phenomena as the efforts to escape from the grip of the West, it increasingly supported the public responses in no time. Various social and cultural actions happened in many places, just like a nationalization process continuation. Thousands of Dutch people were expelled from the Republic of Indonesia, accompanied by various demonstrations performed by workers and artists, making the atmosphere tense. The Dutch government got angry and felt offended by the actions committed by the citizens. What forms of socio-cultural actions took place after the nationalization of Dutch companies in 1958? This study aimed to obtain in-depth pictures of various forms of socio-cultural actions performed by wider communities (especially workers and cultural actors) in the context of nationalization in Indonesia. This study used a library method by tracing primary and secondary data sources and analyzing them after testing the validity. The research results show that the format of sociocultural actions tended to be in mass mobilization and debates in parliaments and mass media.
\end{abstract}

\section{Introduction}

After the nationalization of Dutch companies in the late 1950s in Indonesia, sociocultural responses have been frequently forgotten in many discussion topics. Moreover, the 1950s decade was also known as the disappearing decade due to the bad stereotypes given by the New Order rulers [1]. However, some argued that in the 1950s, a dynamic democratic struggle happened, and then people can now evaluate whether that era was categorized as a golden or dark era [2]. The research conducted by Remco Raben focuses on the presence of high awareness and enthusiasm from both national and local elites for the nation's development in the 1950s, although without the realization of promises to Democracy and economy [3]. Meanwhile, Nasrun Hamdani showed the importance of highlighting the role of local culture in the 1950s as one integrative factor. Nasrun took Sauti, a Malay cultural activist, as his research subject [4].

Corresponding author: wwardojowaskito@gmail.com 
The golden age is understood as a time when stakeholders such as politicians, executives, cultural actors (artists or writers) and company workers can more freely and openly express their aspirations. Many quality and substantive debates occurred to find the solutions to specific problems as if not affected by the people's weak economic conditions after the independence wars.

Apart from the above categories, at the end of the 1950s until the middle of the 1960s, it was crucial for Indonesian history after Soekarno dismissed the Constituent Assembly, returned to the 1945 Constitution, and declared the implementation of guided Democracy. "The Revolution is not finished" and "Politics is the Commander" had become Sukarno's powerful slogans to gain the people's sympathy to support his policies. The anti-foreign phenomena reached the climax along with policies nationalizing the Dutch companies and retaking West Irian. Law no. 86 the Year 1958 on the Nationalization of Dutch Companies triggered various reactions from the Indonesian workers, artists, and writers [5].

This paper focused on explaining the expression formats of both public components. It was known that since the early 1950s, the workers had urged the government to cancel the Round Table Conference (known as Konferensi Meja Bundar) results considered more favourable for the Dutch and weakened the Indonesian economy. The Labor Union (Serikat Buruh) took over the Dutch companies in various parts before implementing the nationalization policy. The military involved in this case was the Army taking over these companies. Even after implementing the Nationalization Law, the Labor Union continuously urged the government to postpone the Foreign Investment Law [6]. In this situation, the state is declared in a state of military emergency so that the military has the authority to take some strategic policies [7]. Meanwhile, the contribution of artists and writers is also significant in figuring out the Indonesian cultural identity. The relationship between literature, writers, and authority in the 1950s was also influential, marked by various important debates shown in various mass media [8].

\section{Method}

This research used a historical method consisting of heuristics, criticisms, interpretations, and historiography [9]. Heuristics means collecting sources from the concerned eras in printed materials and relevant written sources [10]. This method was combined with the library method relying on the tracing of both primary and secondary sources. The tracing was performed to various institutions having some accountable online databases so that the digital tracing processes were also still accountable. The data sources and reference tracing were performed in the national library and both Indonesian and Dutch National Archives.

\section{Results and Discussion}

\subsection{Forms of Social Actions Made by Workers after Nationalization}

Workers acted as the economic and company operation driver and had the power as a pressure group, especially those joining as the members of Labor Unions. They frequently made demonstrations affecting the political or social world at both regional and national levels. Dutch company workers made various movements or coordination as the members of several regional Labor Unions or those affiliated with specific organizations. When performing their actions, these workers can damage the company's orders.

The workers' actions started long before the Dutch company nationalization policy was introduced in 1958. From the early 1950 s to 1957 , various actions made by the labour unions 
from various companies had put political pressure on business people, parliament and government. The number of Dutch companies taken over by labour unions at the end of 1957 had reached 700 companies spread throughout Indonesia. $70 \%$ of foreign companies operating in Indonesia. Since there were many nationalization actions, the ownership of $90 \%$ of plantation production had been transferred to the Indonesian government, including $60 \%$ foreign trade values and about 246 factories, mining, banking, shipping, and other service sectors [11].

The labour unions previously working for the Dutch banks had made coordination before taking over the companies. When the discourse on the nationalization of the Indonesia Bank developed, the labour unions had urged the government to perform the nationalization. The other actions made by the bank labour unions related to the nationalization happened in Jakarta. These actions took place earlier than those that happened at Indonesia Bank. These workers' actions taking place in several Dutch banks were longer and more complicated due to the challenges given by their superintendents [12].

The workers joining as the members of SBBSI (All Indonesia Bank Labor Unions) had taken over Dutch-owned banks in Jakarta, such as NHM (Nederlandsch Handelmaatschappij) and Escompto. These actions were challenged by the directors of Dutch banks, arguing that the acquisition was illegal because their assets should have been acquired or controlled by the military in accordance with the instructions given by the minister of defense. The workers' movement to nationalize the assets, apart from taking over, was also provoked by closing the bank names and replacing them with the writing mentioning that Indonesia had owned the bank. This movement caused the customers to panic, and massive money-taking actions were made at that time [13].

The The workers' actions were quite solid to support the nationalization and programs made by the government by making strikes. The strikes made by the labour unions were intended to show their strength, solidarity and weaken the company's bargaining position. The labour unions in Surabaya held a strike. The workers still went to work, but they did not do any working activity. The strike in Surabaya was made peacefully. This strike was performed in the Dutch-owned and joint-venture companies to support the liberation of West Irian.

SOBSI also initiated the mass labour strike, a labour union affiliated with the Indonesian Communist Party (PKI/Partai Komunis Indonesia). The workers' organs hardly and loudly opposed various foreign/Dutch activities [14]. On 30 November 1957, it was reported that many Dutch companies in Indonesia were taken over by the workers, most of whom were affiliated with the Indonesian Communist Party. However, in the view of Kartini, as the Information Council, she denied that this strike was infiltrated by communist organizations or ideologies [15].

The voices of workers in this nationalization program were not entirely performed with "street action", but with their diplomatic power and pressure affecting the decisions made by the government and companies. The 6th Metal Industrial Labor Union Congress resulted in demands for nationalization and increased labour wages [16].

Based on the increasingly corporate takeover phenomena, there were two different views, especially related to who made the initiative to take action, purely by the workers or based on the orders given by the government. The first view said that the workers' actions were unplanned and not related to the government programs. Meanwhile, the second view said that, based on the reality found in the field, those companies were indeed taken over based on the government orders to be placed under the state supervision [17]. PM Juanda seems to follow the second opinion, saying that the Dutch made a reactive action on the takeover. There were indications of capital movements or transfers of Dutch assets out of Indonesia secretly by the Dutch entrepreneurs. Apart from those indications, there was a social impact resulting from the takeover of these companies, such as the repatriation of 
Dutch citizens from Indonesia. Until August 1958, approximately 35,500 Dutch citizens were repatriated, and only around 6,000 Dutch citizens still stayed in Indonesia.

\subsection{The Role of Artists and writers at the End of 1950s to 1966}

What What was the role of artists and writers in responding to the political atmosphere in Indonesia from the late 1950s to 1966 ? The role of artists in those years could not be separated from the debates between the People's Arts Institute (Lekra) and Cultural Manifesto in the early 1960s. The first group was an artist institution affiliated with the Indonesian Communist Party (known as PKI/Partai Komunis Indonesia), emerging in the early 1950s and introduced socialist realism based on Marxist thoughts. Lekra was initially driven by 15 writers, including Joebaar Ajoeb, A.S. Dharta, MS. Ashar, Herman Arjuno, Pramoedya Ananta Toer, and Njoto. This group seemed to be a buffer institution for Soekarno regime in supporting socialist ideas, including when the government issued a nationalized Dutch company in 1958. Lekra used the folk culture concept as a form of its struggle. People's culture, in this case, was understood as a representative of a wider community oppressed by Dutch imperialism. Lekra positioned itself as an anti-colonial institution in various forms both through the influences of foreign ideologies and economic and political fields. Thus, the state that the Indonesian people supported by Lekra would form was the People's Democratic Republic. The people were given the freedom to manage the independence of the economy, industry, and arts by relying on people through revolution [18]. For Lekra, the way was for Indonesian people and the members of the international community, especially farmers and workers. According to the Lekra preamble in 1950 and renewed at the Lekra Congress in Solo in 1959, the people's culture serves as the struggling ammunition to destroy global imperialism and capitalism.

Lekra had the jargons, such as Arts for Public [Seni untuk Rakyat], Politics is the Commander [Politik adalah Panglima], Expanding and Escalating [Meluas dan Meninggi], and Down-Going Movement [Gerakan Turun ke Bawah]. Soekarno's revolutionary ideas seemed to be interpreted as arts for politics to become artists and writers who supported Soekarno [19]. Lekra had the vehicles as the narrative publishers covering Harian Rakjat and Bintang Timur as a political and ideological organ. The Harian Rakjat Newspaper published poems or opinions made by the artists and observers who supported Lekra. Meanwhile, Bintang Timur had a rubric called Lentera which became the rubric for publishing literary works in the past.

Meanwhile, several writers, such as Wiratmo Soekito, HB Jassin, and Goenawan Mohamad, were driven by the cultural manifesto. This group consisted of artists bringing their ideas, criticizing the government, and rejecting the ideas of socialist realism [20]. The initiators of the Cultural Manifesto emerging in 1963 consisted of 16 writers, 3 painters and 1 composer. In general, the artists were still young at the average of 20 years old with minimal experience. The painters had never had a solo exhibition, while the writers had not yet produced poems and books. With this declaration, the group was called a counterrevolution, a stamp for committing crimes in the past [21]. The initial idea of the Cultural Manifesto was written as follows.

We, Indonesian artists and intellectuals, hereby announce a Cultural manifesto stating our national culture establishment, ideals and politics. For us, culture is a struggle to improve the human life conditions. We don't prioritize one cultural sector above others: Each sector fights together for that culture in accordance with their nature. In performing our national culture, we try to honestly and sincerely create our works as a struggle to maintain and develop our dignity as Indonesian people in the middle of the nations' peoples. Pancasila is our cultural philosophy $[22]$. 
Later, Goenawan Mohamad considered the idea of the Cultural Manifesto entirely created by Wiratmo Soekito to be humanist and aimed at expressing art independence, yet loose [23]. However, the Cultural Manifesto group, which was initially opposed to Lekra, also seemed to enter the political area, although, in the beginning, they were not involved in politics. Choosing not to be involved in politics was a political attitude. As stated by HB Jassin, the foundation of the Cultural Manifesto group was religious morality. It did not choose either left or right party and only adhered to humanity [24]. Cultural Manifesto with Universal Humanism leaned towards the Western world without tracing the local traditions.

If Lekra was supported by a strong political party (Indonesian Communist Party known as $P K I)$ at that time, the Cultural Manifesto was then supported by the military, in this case, the Army. In this context, their debates could not be separated from the struggle for discourse space to influence wider communities. When illustrated as a battlefield, the Indonesian Communist Party, known as PKI, fought against the military, while the workers and artists were behind those actions. Soekarno then banned all activities of Manikebu (a named Cultural Manifesto) in 1964 because there was no other manifesto besides the political manifesto. The debates between Lekra and Manikebu became political issues. They were not texts stated in the Cultural Manifesto at the agenda of the Indonesian Writers Conference (known as KPPI/Konferensi Karyawan Pengarang Indonesia) in March 1964. With military supports, the event was successfully held. However, it did not meet the target since the Lekra group increased their attack intensity against Manikebu, which was led by a military intelligence named Wiratmo Soekito [25].

\section{Results and Discussion}

The The responses given by the worker's community in Indonesia had occurred since the movement era. They even continued until the formation of the Republic of Indonesia by participating in the wars against colonialism through various ways and strategies in accordance with their functions as factory or local or foreign company workers. Artists and writers had also contributed to supporting independence. When the capital was moved from Jakarta to Yogyakarta, the artists also moved and performed various artistic acts as a form of support for the state, including various works and writings in the form of poetries, novels, paintings, and even posters containing provocative invitations or agitations to fight against the Dutch colonialism.

The role of workers, artists, and writers in the 1950s and middle of the 1960s was crucial in the Indonesian national journey. Fierce debates between Lekra, Manikebu, and other groups must be seen as an effort to form a national cultural identity with a broad-minded and non-partisan. The nationalization of foreign/Dutch companies was only one part of episodes that all elements of a sovereign nation must pass.

The socialist cultural identity promoted by Lekra failed following the political events on 30 September 1965. Due to the regime changes from Soekarno to Suharto in 1966, the cultural climate became contradictory and no longer leaning towards communism-socialism but idealism in creating a new culture based on the new values and abandoning the old ones.

The nationalism of the 1950s was understood by artists and intellectuals with the same idea known as the Indonesian-ness reconstruction or rebuilding Indonesia after the 1965 civil war by especially considering the implications of events on 30 September 1965, which caused deep and severe wounds for both parties. The debates between Lekra and Manikebu group were similar to those in the Cultural Polemic occurring before the independence. However, all parties aimed at laying the foundation for the Indonesian-ness identity, orientation, and construction. This included the actions of workers who made agitation and demand against the government and the contestation of artists and writers in the 1950s to 1960s. The demand 
of the Labor Union to the government to nationalize the Dutch companies received a positive response. A legal basis was created and ratified through this institution, including the proposed Law Draft on the Nationalization of Dutch Companies.

Meanwhile, the Dutch did not expect Indonesia to repatriate thousands of its citizens from Indonesia as part of the nationalization of Dutch companies and political pressure as strategies to seize West Irian. The arrival of thousands of citizens previously living comfortably in Indonesia made the Dutch overwhelmed in providing jobs. Thousands of its citizens were forced to become workers and unskilled labourers, the professions they had never imagined before, a job that was frequently ridiculed and avoided when they were in Indonesia.

\section{Acknowledgement}

In this opportunity, the writer would like to thank DIRSIMLITABMAS for the supports and funding under the Research for Doctoral Dissertation Program (225-06/UN7.6.1/PP2021).

\section{References}

1. These terms were developed by Ruth Mc Vey, See in Adrian Vickers, "Mengapa tahun 1950-an penting bagi kajian Indonesia", at Perspektif Baru Penulisan Sejarah Indonesia (The New Perspective Indonesian) Historiography (2008)

2. Pergulatan Demokrasi Liberal 1950-1959 [The Struggle of Liberal Democracy in 19501959]. Zaman Emas atau Hitam [Golden or Dark Era], (2019)

3. Remco Raben, Bangsa, "Daerah, dan Ambiguitas Modernitas di Indonesia tahun 1950an [Region and Modernity Ambiguity in Indonesia in 1950s]", in Sita van Bemmelen and Remco Raben (eds), Antara Daerah dan Negara Indonesia tahun 1950-an: Pembongkaran Narasi Besar Integrasi Bangsa [Between Regions and Indonesian Country in 1950s: Uncovering the Great Naration of State Integration], (2011)

4. Nasrun Hamdani, "Menjadi Indonesia [Becoming Indonesia]" di Tahun 1950-an [in 1950s]: Sauti, Tari Serampang XII, and Kebangkitan Melayu di Sumatera Utara [The Raise of Malay in North Sumatera]", Handep, Jurnal Sejarah dan Budaya [Journal of History and Culture]. Vol 3, No.2 (June 2020)

5. Bondan Kanumuyoso, Nasionalisasi Perusahaan Belanda [Nationalization of Dutch Companies], Jakarta, 2001. Also See D.S Moeljanto, Taufiq Ismail, Prahara Budaya [Cultural Incidents], Kilas Balik Ofensif Lekra/PKI [Flashback of Offensive Lekra (Indonesian "Institute of Peoples" Culture)/Indonesian Communist Party], (1995)

6. See the Archive of the Cabinets of President of the Republic of Indonesia No. 1658 on Surat-Surat Pernyataan Serikat Buruh tentang RUU Penanaman Modal Asing [ Statement Letters of Labor Unions on the Law Draft of Foreign Capital Investment]. See the Archive of SOBSI No. 240 on pengambilalihan modal dan perusahaan asing di Indonesia [The Takeover of Foreign Capitals and Companies in Indonesia], 3 February 1959, also the archive of SOBSI No. 70 on Surat Pernyataan SBKA tentang persoalan politik [SKBA Statement Letter on Political Affairs], ANRI, Jakarta

7. Yahya Muhaimin, Bisnis dan Politik [Business and Politics], (1990)

8. Goenawan Mohamad, Kesusasteraan dan Kekuasaan [Literature and Authority] (1993)

9. Dudung Abdurrahman, Metode Penelitian Sejarah [Historical Research Method], (1999) 
10. Louis Gottschalk, Mengerti Sejarah [Understanding History], translated by Nugroho Notosusanto, (1986)

11. Kementerian BUMN [Ministry of State-Own Enterprises], Sejarah Nasionalisasi Asetaset BUMN [The Nationalization History of State-Owned Enterprises], (2014)

12. "Bank2 Belanda di Jakarta dijaga buruhnja [Dutch Banks in Jakarta were Guarded by its Workers]" Pewarta Surabaya, (5 November 1957)

13. "Seluruh Bank Belanda di Djakarta diambil-alih buruhnja [All Dutch Banks in Jakarta were taken over by its Workers]" Pewarta Surabaya, (12 December 1957)

14. Mengenai aksi pemogokan buruh dan dan infiltrasi PKI di serikat buruh [Related to the Labor Strike and Infiltration of the Indonesian Communist Party in Labor Unions], See: "Perusahaan" Belanda di S'baja Lumpuh [ The Dutch Companies in S'baja were Paralyzed]", Pewarta Surabaya November 1957; Khabibab, "Pemikiran dan Kebijakan Partai Masyumi Terhadap Nasionalisasi Perusahaan Belanda di Indonesia 1945-1958 [ Khabibah, Ideas and Policies of Masyumi Party on the Nationalization of Dutch Companies in Indonesia in 1945-1958]" undergraduate Thesis from the Faculty of Cultural Sciences,Universitas Gajah Mada. (2016). See also Tan Malaka, Gerpolek Gerilya-Politik-Ekonomi [Gerpolek:Guerilla, Politics, and Economy], (1948)

15. "Pengoperan milik Belanda di Indonesia bukan oleh golongan Komunis? [The Dutch Assets in Indonesia were not taken over by] Communist Group?", Pikiran Rakjat, (14 January 1958)

16. Surabaya Post, 19 June 1956; "Beberapa perkebunan di Djatim diserahkan kepada buruhnja [Some Plantations in East Java were handed over to the Workers]", Pewarta Surabaya, (15 December 1957)

17. Dwi Susanto, Sejarah Sastra [Literature History] (Period of 1950-1965) (2016)

18. Jacob Sumardjo, Lintasan Sastra Indonesia Modern [Modern Indonesian Literature Trajectory] (1992)

19. Goenawan Mohamad, Seni, Politik, Pembebasan [Arts, Politics, and Freedom] (2018)

20. Goenawan Mohamad, Kesusastraan dan Kekuasaan [Literature and Authority] (1993)

21. Dwi Susanto, Sejarah Sastra [Literature History] (Period of 1950-1965) (2016)

22. Ajip Rosidi, Ikhtisar Sejarah Sastera Indonesia [Overview of Indonesian Literature History] (2011)

23. Foulcher, Keith, Social Commitment in Literate and the Arts: the Indonesian 'Institute of People Culture" 1950-1960 (1986) 